OPEN ACCESS

Edited by:

Hilary M. Swain, Archbold Biological Station,

United States

Reviewed by:

Albertus J. Smit,

University of the Western Cape,

South Africa

Benny K. K. Chan,

Academia Sinica, Taiwan

${ }^{*}$ Correspondence:

Alexis M. Janosik

ajanosik@uwf.edu

Specialty section:

This article was submitted to Biogeography and Macroecology, a section of the journal

Frontiers in Ecology and Evolution

Received: 23 December 2020 Accepted: 02 September 2021

Published: 22 September 2021

Citation:

Kleinschmidt JM and Janosik AM

(2021) Microplastics in Florida,

United States: A Case Study of Quantification and Characterization With Intertidal Snails.

Front. Ecol. Evol. 9:645727. doi: 10.3389/fevo.2021.645727

\section{Microplastics in Florida, United States: A Case Study of Quantification and Characterization With Intertidal Snails}

\author{
Jordan M. Kleinschmidt and Alexis M. Janosik* \\ Department of Biology, University of West Florida, Pensacola, FL, United States
}

Concentrations of microplastics are increasing within the oceans, including waters surrounding Florida, United States. Miles of sandy beaches make the sunshine state a prime tourist destination leading to an increased amount of pollution along Florida coasts. Microplastics can cause damage to intertidal organisms, as well as causing issues up the food chain with biomagnification and seafood consumers, such as humans. Florida is also subject to hurricanes which often distribute sediments, filling the water column with previously settled microplastics. These factors make Florida a special case to review considering the state is affected heavily by hurricanes and tourism, which can contribute to microplastic concentrations in the Gulf of Mexico. The focus of this study was to quantify, characterize, and compare microplastics contamination in two predatory marine snail species from intertidal habitats in Florida, United States Ingestion results were also compared to microplastics contamination of water samples collected from the same locations. Red-mouth rock shell (Stramonita haemastoma, $n=30$ ) and Crown conch (Melongena corona, $n=30$ ) snails were collected from intertidal habitats in Florida and digested for microplastics quantification. Water samples were filtered and microplastics were quantified. 256 microplastics, of which 93\% were microfibers and $7 \%$ were microfragments were isolated from snails $(n=60)$. Additionally, 67 microplastics were isolated from $8 \mathrm{~L}$ of seawater $(8.375$ microplastics/L), of which $97 \%$ were microfibers and $3 \%$ were microfragments. This is the first known study to demonstrate microplastics contamination of tissues in predatory marine intertidal snails. Marine intertidal snails may be good organisms for biomonitoring of microplastics in intertidal sandy habitats.

Keywords: marine pollution, Stramonita haemastoma, Melongena corona, Gulf of Mexico, microfibers, microfragments

\section{INTRODUCTION}

Marine pollution, in particular plastic pollution, is widely recognized as a global issue (Shim and Thomposon, 2015). Plastic pollution is ubiquitous in the ocean and accounts for upwards of $60-80 \%$ of marine debris (Derraik, 2002). As a result of great durability, plastic persists in marine ecosystems from hundreds to thousands of years (Barnes et al., 2009). Of particular focus 
for this study, microplastics are defined as small pieces of plastic debris that measure $5 \mathrm{~mm}$ or less in size (Von Moos et al., 2012). Microplastics originate from direct manufacturing of small plastics for beauty products or other manufactured goods such as (primary microplastics), or from the degradation and breakdown of larger plastic debris (secondary microplastics) (Hale et al., 2020). Globally, estimates of total microplastics in the ocean range from 5.25 to 125 trillion pieces (Cozar et al., 2014; Lindeque et al., 2020).

Though microplastics are found in water bodies all over the world (Rezania et al., 2018), microplastic debris is most prevalent within the ocean (Ivar do Sul et al., 2013). Microplastics in aquatic ecosystems originate from both land-based and sea-based sources and can make their way to marine ecosystems through runoff, industrial activity, human activities such as tourism and textile industries, and from sewage treatment plants (Rezania et al., 2018). Primary microplastics originate from spillage during the production or recycling or as micro-cleansing beads in personal care products such as facial scrubs and toothpastes are washed into aquatic ecosystems (Anderson et al., 2017). Secondary microplastics most commonly originate from marine litter, laundry discharge, discharge from landfills, and industrial or agricultural sources (Rezania et al., 2018; Hale et al., 2020).

Microplastics in aquatic environments are considered to be a serious issue and threat to aquatic ecosystems and the organisms that inhabit these ecosystems. Many studies have been conducted in the marine environment, from tropical to polar ecosystems, to characterize and quantify microplastics contamination in marine systems (Barnes et al., 2009; Wessel et al., 2016; Waller et al., 2017). Further, due to their small size, microplastics are bioavailable to many organisms across trophic levels. Microplastics have been documented negatively affecting the fecundity, growth, and feeding rates of zooplankton. Though the documented effects on zooplankton are categorized as sublethal, the microplastics can prompt transgenerational mortality effects (Yu et al., 2020; Yu and Chan, 2020). Several studies have demonstrated contamination of microplastics in marine organisms with various feeding strategies such as marine invertebrates, fishes, mammals, and birds (Brillant and MacDonald, 2000; Besseling et al., 2012, 2015; Browne et al., 2013; Cole et al., 2013; Romeo et al., 2015; Carlin et al., 2020). Although it is not clear yet how microplastics might affect human health, evidence from aquatic organisms shows that microplastics cause negative effects on organism growth, metabolism, reproduction, and lead to weakened immune systems (Wright et al., 2013; Costa et al., 2015; Lu et al., 2016; Sussarellu et al., 2016). Humans rely heavily on aquatic biodiversity and ecosystems, both of which are greatly impacted by microplastics.

\section{Microplastics in Florida}

Peninsular Florida (United States), is surrounded by the Gulf of Mexico on the west side and the Atlantic Ocean on the east side. Waters surrounding Florida are polluted with a variety of debris, including microplastics, resulting from anthropogenic activity. Specifically, several studies have quantified microplastics from both seawater and sediment samples from Florida. For example, McEachern et al. (2019) quantified microplastic contamination from surface seawater and sediment samples from Tampa Bay, Florida, with seawater samples ranging from 0.25 to 7.0 particles/L and sediment samples ranging from 30 to 790 particles/kg. In a study by $\mathrm{Yu}$ et al. (2018), occurrence and distribution of microplastics was determined from sand samples in Florida from Dry Tortugas National Park, Everglades National Park, Biscayne National Park, Canaveral National Seashore, Fort Matanzas National Monument, and Timucuan Ecological and Historical Reserve. Counts of microplastics from these locations ranged from 43 to 253 pieces/kg of sand (Yu et al., 2018). Further, citizen scientists have been employed throughout the Gulf Coast of the United States to quantify nurdles, or plastic pellets that are manufactured to melt down to make plastic products, along shorelines. Approximately 12\% of the sampling sites of this citizen science project were along the Gulf Coast of Florida. Interestingly, very few nurdles were collected along the coast of Florida, while 20 of the highest standardized counts were collected in Texas, close to the location where the majority of nurdles are manufactured in the United States (Tunnell et al., 2020).

Microplastics have also been documented in a variety of organisms that live in or associated with waters surrounding Florida, such as osprey, fishes, jellyfish, oysters, mud crabs, sand dollars, and sea cucumbers (Phillips and Bonner, 2015; Waite et al., 2018; Carlin et al., 2020; Iliff et al., 2020; Plee and Pomory, 2020). For example, Carlin et al. (2020) quantified the abundance of microplastic accumulation in gastrointestinal tracts of birds of prey in central Florida and found that all birds examined contained microplastics. Further, Waite et al. (2018) digested oysters (Crassostrea virginica) and mud crabs (Panopeus herbstii) from an estuary along the east coast of central Florida and discovered 1,482 microplastics from 90 oysters and 1,979 microplastics from mud crabs, with microfibers being the most common type of microplastics. Microplastic contamination can have negative impacts, such as false satiation, reproductive complications (Auta et al., 2017), and toxicological impacts (Ogunola et al., 2018) on marine organisms.

Subject to tourism and hurricanes, the state of Florida, may also be particularly vulnerable to marine pollution. Both tourism and storms can increase microplastic pollution in marine ecosystems. Florida has been subject to some of the most catastrophic storms and hurricanes that have been recorded in the United States (Malmstadt et al., 2009). Hurricanes can increase the amount of microplastics transferred from land to water, thus expediting the process of the pollutants entering the ocean (Barnes et al., 2009). Further, storms that disturb sediments can also move and resuspend once settled microplastics throughout the water column (Von Moos et al., 2012). Hurricanes and other natural phenomena can also transfer more personal products, and potentially microplastics into the ocean (Duis and Coors, 2016). Florida has been named the "tourism capital of the world" in reference to the vast number of theme parks and tourist destinations (Carlin et al., 2020). In South Florida during the winter months, Wightman (2020) observed an increase of microplastics in the water column. This observation correlated with the increased tourism during the wintertime which left a higher amount of litter on the beaches, 
and a higher amount of microplastics being washed down drains (Wightman, 2020). With increased tourism and the frequent occurrence of hurricanes, the waters surrounding Florida and the organisms that inhabit these waters become a special case to study microplastics.

\section{Case Study With Snails in Florida}

The species Stramonita haemastoma (Red-mouth rock shell) and Melongena corona (Crown conch) are both predatory gastropod molluscs that can be found in coastal intertidal areas and are the focus of species of this case study in microplastics contamination. Both species of snails are commonly seen clinging to rocks and marine vegetation, as well as on other organisms such as crustaceans. Red-mouth rock shells feed primarily on filter feeding organisms such as bivalves, gastropods and barnacles (Watanabe and Young, 2005). Crown conchs prey upon bivalves and gastropods, including the Marsh periwinkle (Littorina irrotata) (Randall, 2013). Crown conchs are also known to be opportunistic scavengers preying upon horseshoe crabs and other dead organisms (Hayes, 2003). In general, marine snails serve as a food source for other organisms in the ecosystem, such as whelks, murex (O'Connor, 2018) and stone crabs (Richardson and Brown, 1992; Whitenack and Herbert, 2015), which creates the potential for transfer of microplastics to other organisms, as well as impacts on overall ecosystem health (Walkinshaw et al., 2020). Additionally, neither species of snail migrates great distances, thus any microplastic contamination should be from the localized areas of collection.

The objective of this study was to quantify and compare the amount and type of microplastics present in two predatory species of snails collected from Florida, United States. Ingestion results were also compared to microplastics contamination of water samples collected from the same locations. Red-mouth rock shells from the panhandle of Florida and Crown conchs from Central Florida were examined for microplastics to determine the abundance, type, and size ranges of microplastics ingested by each species. Though Red-mouth rock shells and Crown conchs are both predatory snails and have similar prey items, they are different in size, thus microplastic contamination will be compared between the two.

\section{MATERIALS AND METHODS}

\section{Seawater and Snail Collection}

Both seawater and snails were collected from intertidal beach habitats in Florida, United States. Two major locations of Northwest Panhandle Florida and Central Florida were selected for this study. At each of the two major locations, two sampling sites were selected for seawater and snail collection. Prior to snail collection, at each site, two replicates of $1 \mathrm{~L}$ of seawater were collected in sterile and rinsed $1 \mathrm{~L}$ Nalgene bottles. Immediately before collection of seawater samples, Nalgene bottles were dipped in the seawater and rinsed three times before a final dip for collection. Nalgene bottles were immediately sealed in order to prevent contamination. Stramonita haemastoma samples $(n=30)$ were collected haphazardly by hand from
Shoreline Park (30.3540883 N, 87.1752466 W), 3- Mile Bridge (30.3741196 N, 87.1795937 W), in Pensacola Florida (Northwest Panhandle Florida). Additionally, Melongena corona samples ( $n=30$ ) were collected haphazardly by hand from Sand Key Park (27.960541 N, 82.824362 W), and Shell Point Park $(27.916478 \mathrm{~N},-82.840774 \mathrm{~W})$, in Clearwater Florida (Central Florida) (Figure 1). Snails were placed into sealable plastic bags, and then placed into the cooler with ice. Upon returning from the field, snails were immediately placed in the freezer still contained in their plastic bags until tissue digestion.

Each of the sites in this study have varying levels of anthropogenic impacts, though not explicitly measured. For instance, Shoreline Park has many daily visitors that use the location for recreational activities such as boating, fishing, and swimming (Shoreline Park South, 2020). The 3-Mile Bridge site has been subject to ongoing construction and many people fish within the area for tourism and fishing. Both Sand Key Park and Shell Point Park are impacted by beach development along with recreational activities (boating, fishing, and swimming). Additionally, the Gulf of Mexico is subject to a long history of tropical storms and hurricanes dating back to the Holocene period (Conner et al., 1989). Over the last 30 years, the Atlantic Ocean averages 14 named storms, of which seven become hurricanes (NOAA, 2021).

\section{Tissue Digestion and Sample Filtration}

Before tissue digestion, individual snails were measured using Neiko 12" calipers to gather measurements on individual shell height, width, thickness, lip height, and lip width. Following shell measurements, soft tissue was removed from the shell using sterile and rinsed forceps. Snails were prepared for tissue digestion according to Claessens et al. (2013). All glassware was thoroughly rinsed with milliQ water prior to digestion to help eliminate microplastics contamination. Frozen individual snails were then transferred to a sterile separate $250 \mathrm{~mL}$ Erlenmeyer flask and $20 \mathrm{~mL}$ of nitric acid was added. Flasks containing individual snails were left overnight at room temperature in a semi-enclosed chemical hood. The nitric acid and snail tissue mixture was then diluted with $200 \mathrm{ml}$ of warm $\left(\sim 80^{\circ} \mathrm{C}\right)$ filtered deionized water. After the addition of warm milliQ water, flasks containing Stramonita haemastoma were completely digested, while flasks containing Melongena corona were boiled for 5 min for complete tissue digestion. Following tissue digestion, the remaining liquid was filtered using a vacuum hand pump through a $0.45 \mu$ gridded cellulose filter (Whatman). To avoid contamination the filtering apparatus, a magnetic $500 \mathrm{~mL}$ filter cup and magnetic filter base were flushed using milliQ water in between each sample and were covered during filtration to help prevent contamination. Each filter was then stored in a sterile Petrislide ${ }^{\mathrm{TM}}$ (MilleporeSigma ${ }^{\mathrm{TM}}$ ) for drying and quantification. To control for microplastics contamination from the air during digestion, a control flask only containing nitric acid (no tissue) was placed alongside flasks during tissue digestion. After digestion, the control flask was also diluted with milliQ water and filtered in the same way. Seawater samples were filtered following the same protocol as the tissue samples. A 1L sample of milliQ water was also filtered to be used as a 


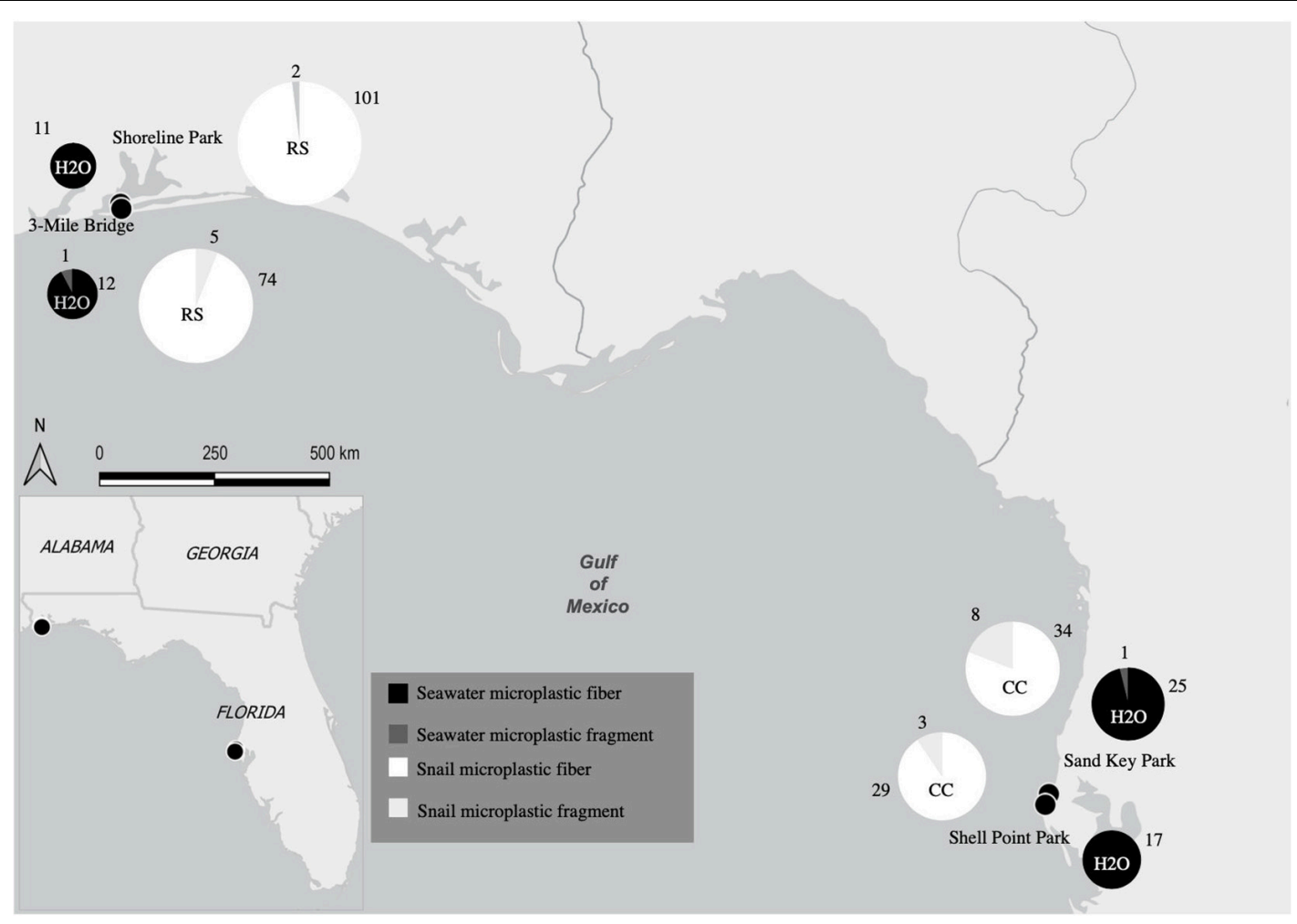

FIGURE 1 | Map showing collection sites and major location of seawater samples and snail tissues as well as the quantity of microplastics from both seawater samples and snail tissue samples. Collection sites Shoreline Park and 3-Mile Bridge are at the major location Northwest Panhandle Florida and collection sites Shell Point Park and Sand Key Park are at the major location Central Florida. Size of each pie graph is correlated to the number of microplastics counted. Both seawater and snail microplastic counts for both microfibers and microfragments and are indicated by colors labeled in the key (RS, Stramonita haemastoma; CC, Melongena corona).

TABLE 1 | Microplastics identified for seawater samples for $2 \mathrm{~L}$ of water.

\begin{tabular}{|c|c|c|c|c|c|c|}
\hline Site name & Date time & Latitude & Longitude & Fibers & Fragments & Total \\
\hline 3-Mile Bridge & 6/15/2020 & 30.3741196 & -87.1795937 & 11 & 0 & 11 \\
\hline Shoreline Park & 6/15/2020 & 27.952523 & -87.8295337 & 12 & 1 & 13 \\
\hline Sand Key Park & 6/20/2020 & 27.960541 & -82.824362 & 17 & 0 & 17 \\
\hline Shell Point Park & 6/20/2020 & 27.916478 & -82.840774 & 25 & 1 & 26 \\
\hline Total & & & & 65 & 2 & 67 \\
\hline
\end{tabular}

Location and abundance of microfibers and microfragments for seawater samples are provided.

Bold values indicate totals of fibers, fragments and total overall.

control for microplastics contamination during the seawater filtration process.

\section{Quantification of Microplastics}

Using a compound microscope (4X and 10X), microplastics on filters from tissue and seawater samples were directly quantified and characterized according to abundance and diversity. Visual identification was employed to differentiate plastics from other natural organic debris (algae, sediment, invertebrates, and plant material). To help ensure proper identification, each suspected microplastic was examined following methods of Whitaker et al. (2019). Specifically, suspected microplastics were examined for cellular and organic structures, for even thickness of fibers, and homogenous color, according to Hidalgo-Ruz et al. (2012).
To further distinguish between organic and plastic material, a metal probe was heated and placed next to the putative plastic. According to Hendrickson et al. (2018), employing a "melt test" will cause plastic fibers to melt, while cotton and wool fibers will burn. Thus, in this study, if an item melted, it was classified as microplastic. Microplastics were categorized by type (microbeads, microfragments, and microfibers), size, and color. Measurements of microplastics were made using Image $^{1} \mathrm{v} 1.52 \mathrm{a}$ bundled with Java 1.8.0_172 for Windows. Photographs of each filter were taken prior to the "melt test" with a Nikon DS-Fi2 microscope and the corresponding soft-ware, NIS-Elements, was used to burn the set scale of $100 \mu \mathrm{m}$ for every photograph. Measuring required the scale to be set on each individual photo,

\footnotetext{
${ }^{1}$ https://imagej.nih.gov/ij/
} 


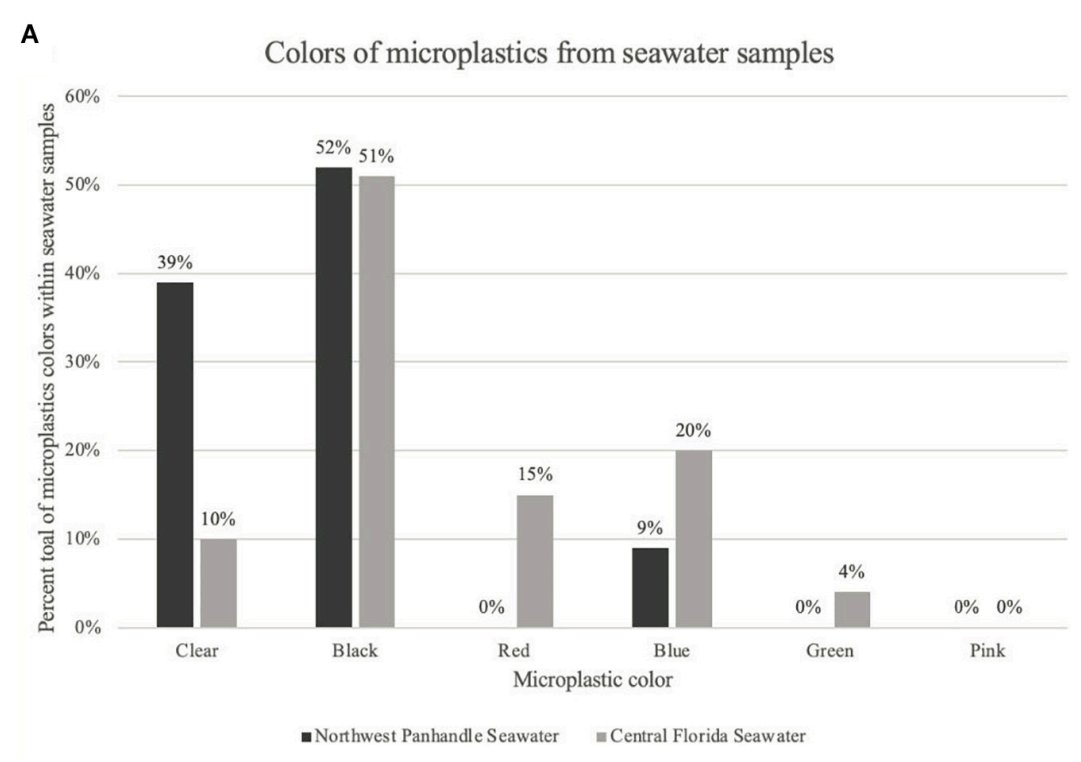

B

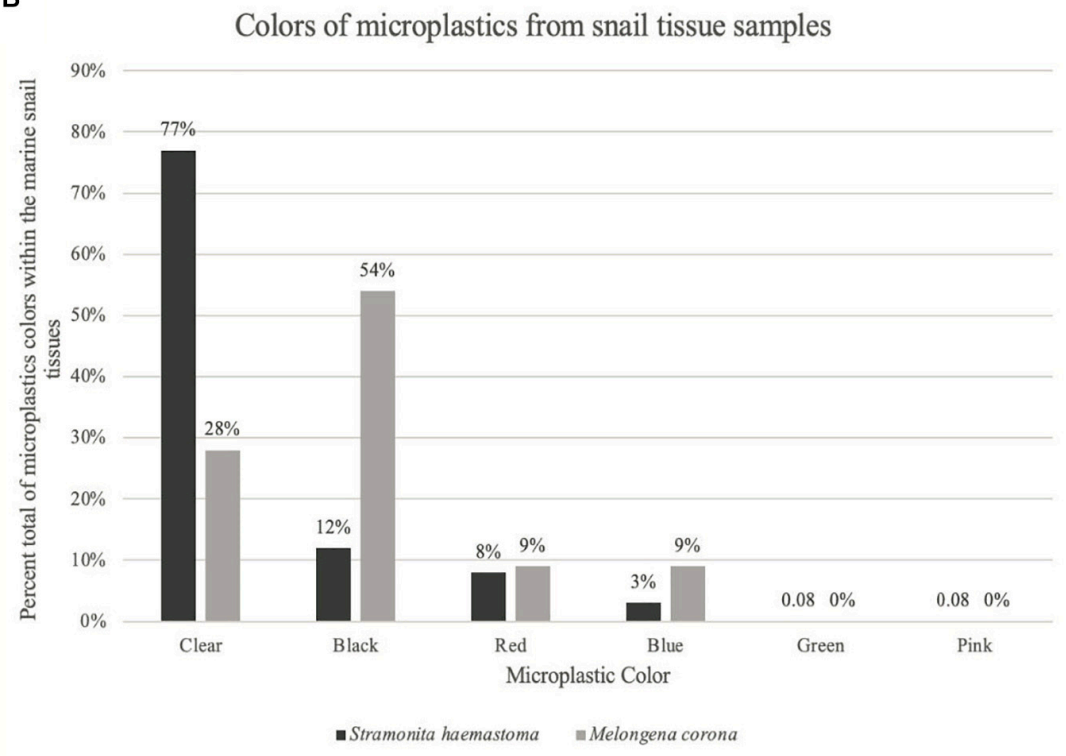

FIGURE 2 | Graph of color distribution of microplastics from seawater samples and snail tissue samples. (A) Shows the percent of each color of microplastics from seawater samples. Dark gray bars correspond to seawater microplastics from Northwest Panhandle Florida and light gray bars correspond to seawater microplastics from Central Florida. (B) Shows the percent of each color of microplastics from snail tissue samples. Dark gray bars correspond to snail tissue microplastics from Northwest Panhandle Florida and light gray bars correspond to snail tissue microplastics from Central Florida.

as each filter had multiple photos to capture all plastic debris. Using the straight-line tool in ImageJ, the scale line was traced and set before beginning measurements. All fibers and fragments were traced using the freehand tool to accommodate twisting and bending of fibers and irregular edges of fragments. Thus, length of fibers and surface area of microfragments were estimated.

\section{Analyses}

Statistical analyses were conducted in R (R Core Team, 2014) and boxplots were produced using the package ggplot2 (Wickham, 2009). A Welch two sample $t$-test was also used to determine if there was a significant difference in shell height between the species of snails (Stramonita haemastoma and Melongena corona) to demonstrate if size differences were apparent of collected specimens between species. To determine if there was a difference in the number of microplastics from filtered seawater samples from the two major locations of this study (Northwest Panhandle Florida and Central Florida) a Wilcoxon rank-sum test with continuity correction was employed (Wilcoxon, 1945). Further, to determine if there was a difference in the number of microplastics from digested tissues between species of snails (Stramonita haemastoma and 
TABLE 2 | Microplastics identified for snail tissue samples.

\begin{tabular}{|c|c|c|c|c|c|c|c|c|c|}
\hline Site Name & $\begin{array}{l}\text { Species } \\
\text { Name }\end{array}$ & $\begin{array}{c}\text { Number of } \\
\text { Snails }\end{array}$ & Date Time & Latitude & Longitude & Snail Fibers & $\begin{array}{l}\text { Snail } \\
\text { Fragments }\end{array}$ & Snail Total & $\begin{array}{c}\text { Mean } \pm \\
\text { microplastics } \\
\text { per snail }\end{array}$ \\
\hline 3-Mile Bridge & $\begin{array}{l}\text { Stramonita } \\
\text { haemastoma }\end{array}$ & 15 & 6/15/2020 & 30.3741196 & -87.1795937 & 101 & 2 & 103 & $6.86( \pm 3.41)$ \\
\hline Shoreline Park & $\begin{array}{l}\text { Stramonita } \\
\text { haemastoma }\end{array}$ & 15 & $6 / 15 / 2020$ & 30.3540883 & -87.1752466 & 74 & 5 & 79 & $5.26( \pm 4.44)$ \\
\hline Sand Key Park & $\begin{array}{l}\text { Melongena } \\
\text { corona }\end{array}$ & 15 & 6/19/2020 & 27.960541 & -82.824362 & 29 & 3 & 32 & $2.13( \pm 1.82)$ \\
\hline Shell Point Park & $\begin{array}{l}\text { Melongena } \\
\text { corona }\end{array}$ & 15 & 6/20/2020 & 27.916478 & -82.840774 & 34 & 8 & 42 & $2.8( \pm 1.79)$ \\
\hline Total & & 60 & & & & 238 & 18 & 256 & \\
\hline
\end{tabular}

Location and abundance of microfibers and microfragments for snail and seawater samples are provided.

For mean microplastics per snail, standard deviation is represented in parentheses.

Bold values indicate totals of snail fibers, snail fragments and snail total overall.

Melongena corona) a Wilcoxon rank-sum test with continuity correction was also used.

One-way Analysis of Variance (ANOVA) with Tukey's multiple comparison adjustment was employed to determine if there was a significant difference in size and color of microfibers between seawater samples collected from two major locations in this study (Northwest Panhandle Florida and Central Florida). Additionally, an ANOVA with Tukey's multiple comparison adjustment was also employed to determine if there was a significant difference between species (Stramonita haemastoma and Melongena corona) by size and color of microfibers contamination in terms of fiber length. Microfragment sizes and colors were not compared between species due to low sample size of recovered microfragments.

To validate that seawater samples were statistically different from filtration milliQ water blanks (control), a Welch two sample $t$-test was employed. Further to validate that snail tissue samples were statistically different from digestion blanks (control), a Welch two sample $t$-test was used.

\section{RESULTS}

In total $8 \mathrm{~L}$ of seawater were collected. Specifically, $2 \mathrm{~L}$ of seawater were collected at each of the following sites: Northwest Florida: Shoreline Park, 3-Mile Bridge; Central Florida: Shell Point Park, and Sand Key Park. Seawater filtration for microplastics revealed a total of 67 microplastics from $8 \mathrm{~L}$ of seawater $(8.375$ microplastics/L), of which $97 \%$ were microfibers and $3 \%$ were microfragments. Specifically, seawater filtration of Northwest Panhandle Florida samples revealed 24 microplastics from $4 \mathrm{~L}$ of seawater (6 microplastics/L), of which $95 \%$ were microfibers and 5\% were microfragments (Table 1 and Figure 1). Seawater filtration of Central Florida samples revealed 43 microplastics from $4 \mathrm{~L}$ of seawater (10.75 microplastics/L), of which $98 \%$ were microfibers and 2\% were microfragments (Table 1 and Figure 1). No microbeads were identified from seawater samples. Microfibers from seawater samples were primarily red, black, translucent, and blue, varying in length ranging from 14 to
$886 \mu \mathrm{m}$. The majority of microfragments from seawater samples were black with one clear fragment and varied in surface area from 169 to $275 \mu \mathrm{m}$. Color distribution of both microfibers and microfragments from seawater samples can be seen in Figure 2.

Tissue digestion for microplastics of 60 snails (Northwest Florida Panhandle: Stramonita haemastoma, $n=30$; Central Florida: Melongena corona, $n=30$ ) showed a total of 256 microplastics, of which $93 \%$ were microfibers and $7 \%$ were microfragments. Specifically, tissue digestion of Stramonita haemastoma $(n=30)$ from Northwest Panhandle Florida revealed 182 microplastics, of which $96 \%$ were microfibers and $4 \%$ were microfragments (3-mile Bridge mean 6.86 ( \pm 3.41), Shoreline Park mean 5.26 ( \pm 4.44); Table 2 and Figure 1). Tissue digestion of Melongena corona $(n=30)$ from Central Florida showed 74 microplastics, of which $85 \%$ were microfibers and 15\% were microfragments (Sand Key Park mean 2.13 ( \pm 1.82 ), Shell Point Park mean 2.8 ( $\pm 3.41 .79)$; Table 2 and Figure 1). The majority of microfibers from snail tissue samples were clear, while others were blue, green, black, red, and pink, with length ranging from 21 to $1492 \mu \mathrm{m}$. Microfragments from snail tissue samples were mostly commonly clear, while others were black, red, and blue and varied in surface area from 48 to $220 \mu \mathrm{m}$. A graph of color distribution of both microfibers and microfragments from snail tissue samples can be seen in Figure 2. A composition of representative microfibers and microfragments for both seawater and snail tissue samples can be seen in Figure 3.

There was no significant difference in the number of microplastics from seawater samples collected from Northwest Panhandle Florida and Central Florida (Wilcoxon rank-sum test: $p=0.3719)$. There was, however, a statistical difference in the number of microplastics from digested tissues between species Stramonita haemastoma (Northwest Panhandle Florida) and Melongena corona (Central Florida) as seen in Figure 4 (Wilcoxon rank-sum test: $p=1.927 \mathrm{e}-05$ ).

Further, there was a significant difference in the size of microplastic fibers comparing the two major locations, Northwest Panhandle Florida and Central Florida seawater samples (ANOVA: $p=0.039 ; F=4.706$; $d f=1$ ). There was also no significant difference between the size of microplastic 


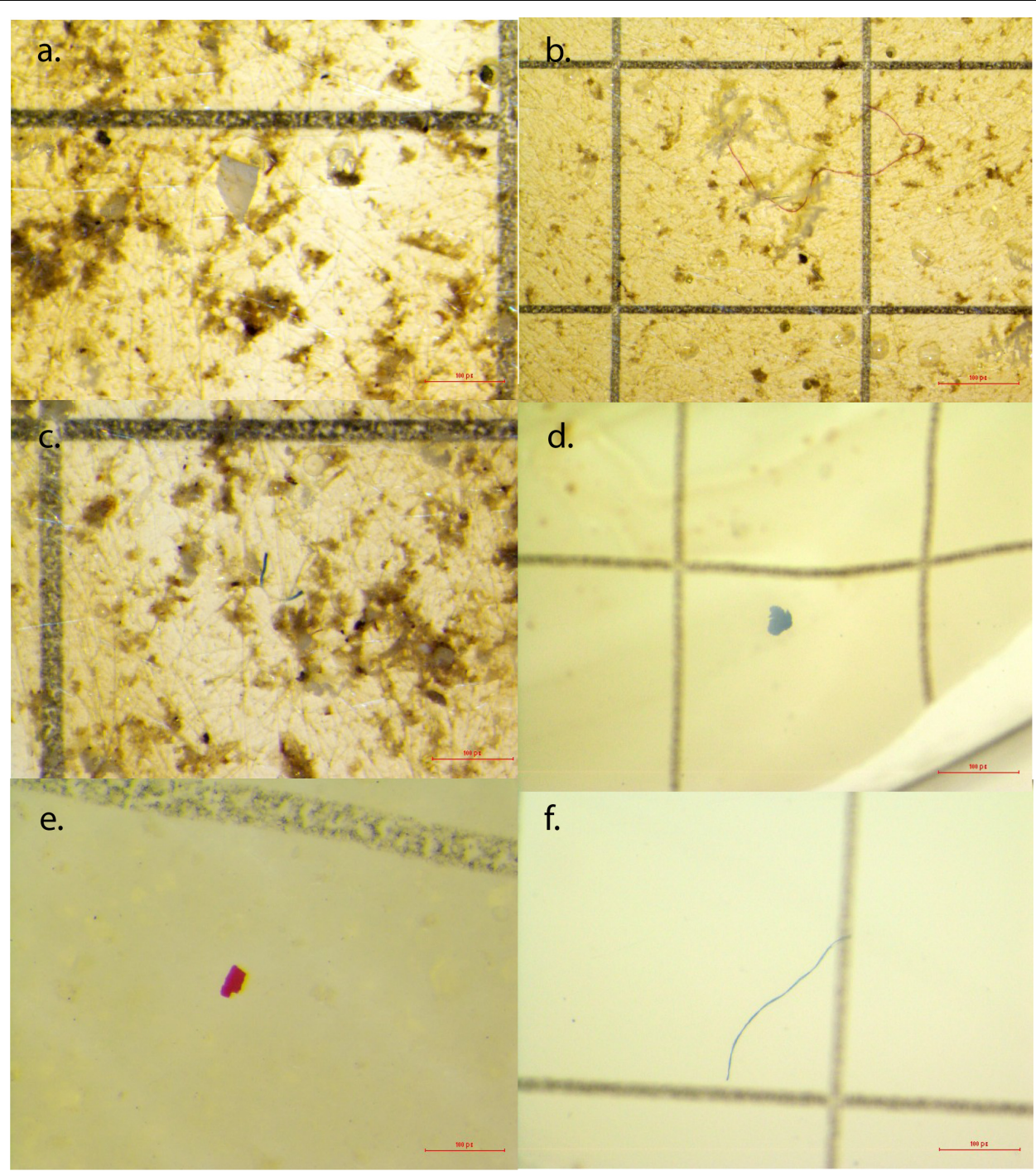

FIGURE 3 | Examples of microplastics from seawater samples and snail tissues. (a) Clear microfragment from Shell Point Park seawater sample; (b) red microfiber from Sand Key Park seawater sample; (c) blue and clear microfiber from Shell Point Park seawater sample; (d) blue microfragment from Crown conch snail tissue from Sand Key Park; (e) red microfragment from Crown conch snail tissue from Shell Point Park; (f) blue microfiber from Red-mouth rock shell tissue from 3-Mile Bridge.

fibers between the two snail species tissue samples, Stramonita haemastoma (Northwest Panhandle Florida) and Melongena corona (Central Florida) (ANOVA: $p=0.53 ; F=0.396 ; d f=1$ ). There was a significant difference in the color of microplastics in seawater samples from the two major sampling locations, Northwest Panhandle Florida and Central Florida (ANOVA: $p=4.17 \mathrm{e}-4 ; F=13.92 ; d f=1)$. Black microfibers dominated the seawater from Northwest Panhandle Florida (52\%) and Central Florida (51\%), however, Northwest Florida had a greater number of clear microfibers, while Central Florida had a greater number of red and blue microfibers. There was also a significant difference in the color of microplastics from digested tissues between Stramonita haemastoma (Northwest Panhandle Florida) and to Melongena corona (Central Florida) (ANOVA: $p=7.09 \mathrm{e}^{-}$ $6 ; F=21.05 ; d f=1)$. Clear microfibers dominated the tissues of
Stramonita haemastoma (Northwest Panhandle Florida), while black microfibers dominated the tissues of Melongena corona (Central Florida) (Figure 2). Given that there were so few microfragments from both seawater and tissue samples (Table 3), they were not included in statistical analyses.

Water filtration blanks had significantly fewer microplastics than seawater samples (Welch two sample $t$-test: $p=2.238 \mathrm{e}-12$ ). Digestion blanks had significantly fewer microplastics than tissue samples (Welch two sample $t$-test: $p=3.502 \mathrm{e}-09$ ).

\section{DISCUSSION}

The results from this study indicate that both seawater and snail tissue samples from Northwest Panhandle Florida and Central 

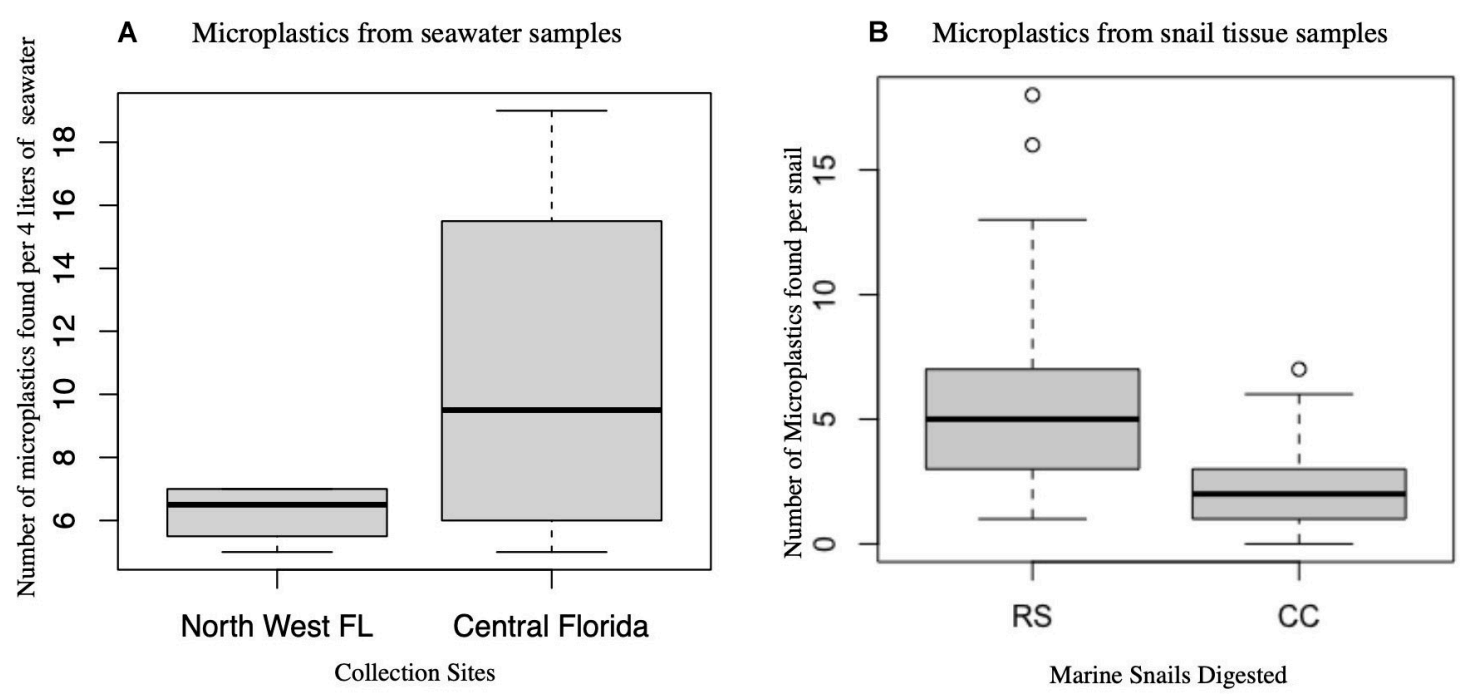

FIGURE 4 | Box plots of microplastics in seawater and snail tissue samples. (A) Microplastics from seawater samples per $4 \mathrm{~L}$ collected from two major locations (Northwest Panhandle Florida and Central Florida) are not significantly different. (B) Microplastics from snail tissue samples between the two species of snails (RS, Stramonita haemastoma; CC, Melongena corona) are significantly different.

TABLE 3 | Body measurements of Stramonita haemastoma from Northwest Panhandle Florida sites (Shoreline Park, 3-Mile Bridge) and Melongena corona from Central Florida sites (Sand Key Park and Shell Point Park).

\begin{tabular}{|c|c|c|c|c|c|c|}
\hline Site & Species & $\begin{array}{l}\text { Height Avr. } \\
\text { (mm) }\end{array}$ & $\begin{array}{l}\text { Width Avr. } \\
\text { (mm) }\end{array}$ & $\begin{array}{c}\text { Shell Thickness } \\
\text { Avr. }(\mathrm{mm})\end{array}$ & $\begin{array}{l}\text { Lip Height } \\
\text { Avr. (mm) }\end{array}$ & $\begin{array}{l}\text { Lip Width } \\
\text { Avr. (mm) }\end{array}$ \\
\hline Shoreline Park & $\begin{array}{l}\text { Stramonita } \\
\text { haemastoma }\end{array}$ & 27.71 & 14.89 & 0.301 & 16.42 & 5.276 \\
\hline 3-Mile Bridge & $\begin{array}{l}\text { Stramonita } \\
\text { haemastoma }\end{array}$ & 26.45 & 15.21 & 0.804 & 16.57 & 7.142 \\
\hline Sand Key Park & $\begin{array}{l}\text { Melongena } \\
\text { corona }\end{array}$ & 45.77 & 27.49 & 0.589 & 31.02 & 11.27 \\
\hline Shell Point Park & $\begin{array}{l}\text { Melongena } \\
\text { corona }\end{array}$ & 51.62 & 30.54 & 1.165 & 35.53 & 13.37 \\
\hline
\end{tabular}

Florida were contaminated with microplastics. The number of microplastics in seawater samples from Northwest Panhandle Florida and Central Florida was not significantly different, though in general there were more microplastics in the seawater samples from Central Florida. There were, however, significantly more microplastics in Red-mouth rock shells (Stramonita haemastoma) that were collected from Northwest Panhandle Florida, when compared to Crown conchs (Melongena corona) that were collected from Central Florida. Possible reasons for this difference in microplastics quantity will be discussed below.

Microfibers were the dominant type of microplastic from both seawater samples (97\% microfibers) and snail tissue samples (93\% microfibers) from Northwest Panhandle Florida and Central Florida, respectively. These results are similar to findings in several other studies both in waters surrounding Florida and other locations around the globe (e.g., Waite et al., 2018; Akindele et al., 2019; Whitaker et al., 2019). Sizes of microfibers from both seawater and snail tissue samples were similar, indicating that fibers are likely being consumed from the environment, transferred indirectly through trophic transfer from prey items of both Red-mouth rock shells and Crown conchs. Microfibers in marine samples originate from a variety of sources including wastewater, clothing, ropes and nets, cigarettes, and fishing activity (Wright et al., 2013; Wang et al., 2018; Hale et al., 2020). Microfragments in marine samples originate from the breakdown of larger pieces of plastic debris. Only a few microfragments $(<3 \%)$ were isolated from snail and water samples, which is similar to findings of other studies (e.g., Waite et al., 2018; Akindele et al., 2019; Whitaker et al., 2019). Though it is not known how microplastics impact Red-mouth rock shells or Crown conchs, microplastic impacts have been demonstrated in several other organisms. For example, microplastic ingestion has been shown to clog and block feeding structures and the digestive tract, thus limiting food intake (Cole et al., 2013). Further, microplastics have been shown to cause a change in behavioral vigilance and predator avoidance in the Common periwinkle (Seuront, 2018). Ingested microplastics may also be transferred to the circulatory system (Browne et al., 2008), 
causing a reduction of feeding activity (Besseling et al., 2012), and an increased immune response (Avio et al., 2015). Ultimately, microplastics may act as vectors for transferring novel bacterial assemblages (Barnes, 2002; Gregory, 2009) and may contain adsorbed chemical pollutants (Carpenter and Smith, 1972; Hale et al., 2020).

In general, feeding strategy and environmental prevalence have been shown to be the main drivers of microplastic consumption (Walkinshaw et al., 2020). As predatory snails, Red-mouth rock shells and Crown conchs are both likely consuming microplastics indirectly through trophic transfer from prey items from their marine environment, though unlikely, microplastic consumption may be occurring directly from the environment. Red-mouth rock shells are smaller bodied compared to Crown conchs. Specifically, Red-mouth rock shells typically reach $40 \mathrm{~mm}$ in length, while Crown conchs reach approximately $120 \mathrm{~mm}$ in length (Limaverde et al., 2007; Masterson, 2008). The snails used in this study are not full length, however, they were significantly different in shell length, with Crown conchs being the larger of the two species. Despite the overall size difference between snail species, the generally smaller bodied Red-mouth rock shells contained significantly more microplastics compared to the generally larger bodied Crown conchs. This difference in microplastic contamination could result from one or more of the following reasons.

Differences in contamination could result from differences in prey items and subsequent microplastic contamination of prey items of each snail. As such, Red-mouth rock shells and Crown conchs, have similar ecological roles, and feed mostly on bivalves, gastropods, and barnacles that are likely directly filtering/consuming microplastics as they feed in the benthos (Bowling, 1994; Watanabe and Young, 2005). In fact, filter feeders have been shown to more effectively consume microplastics from surrounding waters than non-filter feeding organisms (Van Cauwenberghe and Janssen, 2014; Setälä et al., 2016; Gonçalves et al., 2019). Thus, perhaps a difference in microplastic contamination of snails resulted from a difference in contamination of prey items. Further, trophic transfer from snails to other predators could potentially be occurring as the Red-mouth rock shells and Crown conchs consume contaminated prey items, and then are consumed by other predators such as crabs (Brown, 1997) and birds (Krueger, 2021). There is also some evidence to suggest that microplastic contamination of body tissues could also arise from filtration of water through the gills (Watts et al., 2014). Further, there is evidence to demonstrate that filter feeding bivalves such as Crassostrea virginica and Mytilus edulis selectively ingested microplastics preferentially, based on the physical characteristics of the plastic (Ward et al., 2019). A key factor in bioavailability of microplastics is their small size, making them more likely to be available to lower trophic levels (Wright et al., 2013). Thus, it is possible that the Red-mouth rock shells examined in this study consumed prey items that were more contaminated with microplastics, due to preferential selection or retention of microplastics, compared to the prey items of the Crown conchs. Another possible reason that Red-mouth rock shells contained more microplastic contamination is that the snails themselves had microplastic retention or transfer of microplastics into tissues other than the digestive system (Walkinshaw et al., 2020).

Further, a lower concentration of microplastics in the Crown conchs may indicate that microplastics could be egested through the digestive system, instead of being retained or translocated to tissues. Fewer microplastics in predatory Crown conchs could also indicate that microplastics are commonly passed through the guts and released in the feces of prey items, rather than building up in the consumed organisms as was also seen in Littorina littorea (Gutow et al., 2016). Consequently, microplastic contamination likely poses a greater threat to certain species depending upon prey items consumed, retention or lack thereof of microplastics, and place in the food chain (Walkinshaw et al., 2020).

Although there was no significant difference in the number of microplastics in the seawater samples from the two major locations sampled in this study, there was a significant difference in terms of size of microplastics from the two major locations. As such, Northwest Florida Panhandle water samples showed significantly larger microplastics, though snail samples did not show a significant difference in size of microplastics consumed. This may indicate that prey items of both species of predatory snails are possibly selecting and consuming similar sizes of microplastics from the environment. Filter feeding organisms have been shown to show selection based on physical characteristics of microplastics (Ward et al., 2019). It is important to mention that microplastic contamination of seawater can fluctuate with storms and effluence and was only sampled at one place and time in this study. Fluctuations of microplastics in the water could also potentially account for the difference in contamination of snail tissues seen in this study.

There was a significant difference in terms of color of ingested microplastics between the two major locations of this study. Both Northwest Panhandle Florida and Central Florida seawater samples had similar numbers of black microfibers, however, Central Florida seawater samples had a greater number of red and blue microfibers, while Northwest Panhandle Florida had a greater number of clear microfibers. Interestingly, in the snail tissue samples, Red-mouth rock shells from Northwest Panhandle Florida, were contaminated with a greater number of clear microfibers (77\%), while Crown conchs from Central Florida, were contaminated mostly with black microfibers (54\%). Clear microfibers are commonly recovered as the dominant color of microplastics from tissues of organisms such as birds (Zhu et al., 2019; Carlin et al., 2020), fishes (Romeo et al., 2015; Peters et al., 2017) and invertebrates (Waite et al., 2018).

Microplastics have been documented to cause many deleterious effects in a variety of different organisms (see citations above). If microplastics cause deleterious effects (e.g., reduced feeding and reproduction) to the intertidal snails of this study, snail populations could decline. Likewise, a decline in snail populations could cause a trophic cascade impacting food 
availability for other species and ecosystem health (Walkinshaw et al., 2020). In this study, both Red-mouth rock shells and Crown conchs were contaminated with microplastics, which is likely originating from indirect trophic transfer from prey items. It is still questionable if microplastics can be transferred to even higher trophic levels following predation. However, Redmouth rock shells and Crown conch are commonly found in intertidal habitats and serve as prey items for several other organisms in these ecosystems, creating the potential for the trophic transfer of microplastics potentially having an effect on both ecosystem and human health (Carbery et al., 2018; Walkinshaw et al., 2020).

Overall, this is the first study on predatory marine intertidal snails to demonstrate microplastics contamination, indicating these snail species are likely consuming microplastics indirectly through trophic transfer from prey items from their environment. As such, Red-mouth rock shells may have greater contamination of microplastics as a result of increased microplastic contamination of prey items or from retention of microplastics. The results from this study raise substantial ecotoxicological concern for small invertebrate species which are often not the focus of ecological or conservation studies. Understanding the types and abundance of microplastics is necessary for future studies to understand how microplastics move through the food web and how microplastics directly and indirectly impact organisms. Further work is needed to determine the impacts of microplastics on these two benthic species and the overall impact on ecosystem health, particularly for Florida ecosystems.

\section{REFERENCES}

Akindele, E. O., Ehlers, S. M., and Koop, J. H. E. (2019). First empirical study of freshwater microplastics in West Africa using gastropods from Nigeria as bioindicators. Limnologica 78:125708. doi: 10.1016/j.limno.2019.125708

Anderson, P. J., Warrack, S., Langen, V., Challis, J. K., Hanson, M. L., and Rennie, M. D. (2017). Microplastic contamination in Lake Winnipeg, Canada. Environ. Pollut. 225, 223-231. doi: 10.1016/j.envpol.2017.02.072

Auta, H., Emenike, C., and Fauziah, S. (2017). Distribution and importance of microplastics in the marine environment: a review of the sources, fate, effects, and potential solutions. Environ. Int. 102, 165-176. doi: 10.1016/j.envint.2017. 02.013

Avio, C. G., Gorbi, S., Milan, M., Benedetti, M., Fattorini, D., d’Errico, G., et al. (2015). Pollutants bioavailability and toxicological risk from microplastics to marine mussels. Environ. Pollut. 198, 211-222. doi: 10.1016/j.envpol.2014.12. 021

Barnes, D. K. A. (2002). Invasions by marine life on plastic debris. Nature 416, 808-809. doi: 10.1038/416808a

Barnes, D. K. A., Galgani, F., Thompson, R. C., and Barlaz, M. (2009). Accumulation and fragmentation of plastic debris in global environments. Philos. Trans. R. Soc. B 364, 1985-1998. doi: 10.1098/rstb.2008.0205

Besseling, E., Foekema, E. M., Van Franeker, J. A., Leopold, M. F., Kühn, S., Bravo Rebolledo, E. L., et al. (2015). Microplastic in a macro filter feeder: humpback whale Megaptera novaeangliae. Mar. Pollut. Bull. 95, 248-252. doi: 10.1016/j. marpolbul.2015.04.007

Besseling, E., Wegner, A., Foekema, E. M., van den Heuvel-Greve, M. J., and Koelmans, A. A. (2012). Effects of microplastic on fitness and PCB bioaccumulation by the lugworm Arenicola marina (L.). Environ. Sci. Technol. 47, 593-600. doi: 10.1021/es302763x

Bowling, C. (1994). Habitat and size of the Florida crown conch (Melongena corona Gmelin): why big snails hang out at bars. J. Exp. Mar. Biol. Ecol. 175, 181-195.

\section{DATA AVAILABILITY STATEMENT}

The raw data supporting the conclusions of this article will be made available by the authors, without undue reservation.

\section{AUTHOR CONTRIBUTIONS}

$\mathrm{JK}$ and $\mathrm{AJ}$ identified the research question and study approach, carried out specimen collection, designed laboratory methods, and were responsible for manuscript data and writing. JK performed the laboratory methods and data analysis. AJ oversaw data analysis and interpretation. Both authors contributed to the article and approved the submitted version.

\section{FUNDING}

Funding was provided for this study from the Office of Undergraduate Research at the University of West Florida.

\section{ACKNOWLEDGMENTS}

We thank the Office of Undergraduate Research at the University of Florida for funding support and undergraduate research support. We also thank Tristyn Garza for assistance with microplastic identification and measuring and Victoria Bogantes Aguilar for assistance with the map.

Brillant, M. G. S., and MacDonald, B. A. (2000). Postingestive selection in the sea scallop, Placopecten magellanicus (Gmelin): the role of particle size and density. J. Exp. Mar. Biol. Ecol. 253, 211-227. doi: 10.1016/s0022-0981(00)00258-6

Brown, K. M. (1997). Size-specific aspects of the foraging ecology of the southern oyster drill Stramonita haemastoma (Kool 1987). J. Exp. Mar. Biol. Ecol. 214, 249-262. doi: 10.1016/s0022-0981(96)02775-x

Browne, M. A., Dissanayake, A., Galloway, T. S., Lowe, D. M., and Thompson, R. C. (2008). Ingested microscopic plastic translocates to the circulatory system of the mussel, Mytilus edulis(L.). Environ. Sci. Technol. 42, 5026-5031. doi: 10.1021/es800249a

Browne, M. A., Niven, S. J., Galloway, T. S., Rowland, S. J., and Thompson, R. C. (2013). Microplastic moves pollutants and additives to worms, reducing functions linked to health and biodiversity. Curr. Biol. 23, 2388-2392. doi: 10.1016/j.cub.2013.10.012

Carbery, M., O’Connor, W., and Palanisami, T. (2018). Trophic transfer of microplastics and mixed contaminants in the marine food web and implications for human health. Environ. Int. 115, 400-409. doi: 10.1016/j.envint.2018.0 3.007

Carlin, J., Craig, C., Little, S., Donnelly, M., Fox, D., Zhai, L., et al. (2020). Microplastic accumulation in the gastrointestinal tracts in birds of prey in central Florida, USA. Environ. Pollut. 264:114633. doi: 10.1016/j.envpol.2020. 114633

Carpenter, E. J., and Smith, K. L. (1972). Plastics on the Sargasso Sea surface. Science 175, 1240-1241. doi: 10.1126/science.175.4027.1240

Claessens, M., Van Cauwenberghe, L., Vandegehuchte, M. B., and Janssen, C. R. (2013). New techniques for the detection of microplastics in sediments and field collected organisms. Mar. Pollut. Bull. 70, 227-233. doi: 10.1016/j.marpolbul. 2013.03.009

Cole, M., Lindeque, P., Fileman, E., Halsband, C., Goodhead, R., Moger, J., et al. (2013). Microplastic ingestion by zooplankton. Environ. Sci. Technol. 47, 6646-6655. doi: 10.1021/es400663f 
Conner, W. H., Day, J. W., Baumann, R. H., and Randall, J. M. (1989). Influence of hurricanes on coastal ecosystems along the northern Gulf of Mexico. Wetl. Ecol. Manag. 1, 45-56. doi: 10.1007/BF00177889

Costa, E., Gambardella, C., Piazza, V., Greco, G., Lavorano, S., Beltrandi, M., et al. (2015). Effect of neurotoxic compounds on ephyrae of Aurelia aurita jellyfish. Hydrobiologia 759, 75-84. doi: 10.1007/s10750-015-2284-3

Cozar, A., Echevarria, F., Gonzalez-Gordillo, J. I., Irigoien, X., Ubeda, B., Hernandez-Leon, S., et al. (2014). Plastic debris in the open ocean. Proc. Natl. Acad. Sci. U.S.A. 111, 10239-10244. doi: 10.1073/pnas.1314705111

Derraik, J. G. (2002). The pollution of the marine environment by plastic debris: a review. Mar. Pollut. Bull. 44, 842-852. doi: 10.1002/gch2.201900081

Duis, K., and Coors, A. (2016). Microplastics in the aquatic and terrestrial environment: sources (with a specific focus on personal care products), fate and effects. Environ. Sci. Eur. 28:2. doi: 10.1186/s12302-015-0069-y

Gonçalves, C., Martins, M., Sobral, P., Costa, P. M., and Costa, M. H. (2019). An assessment of the ability to ingest and excrete microplastics by filter-feeders: a case study with the Mediterranean mussel. Environ. Pollut. 245, 600-606. doi: 10.1016/j.envpol.2018.11.038

Gregory, M. R. (2009). Environmental implications of plastic debris in marine settings-entanglement, ingestion, smothering, hangers-on, hitch-hiking and alien invasions. Philos. Trans. R. Soc. B 364, 2013-2025. doi: 10.1098/rstb.2008. 0265

Gutow, L., Eckerlebe, A., Giménez, L., and Saborowski, R. (2016). Experimental evaluation of seaweeds as a vector for microplastics into marine food webs. Environ. Sci. Technol. 50, 915-923. doi: 10.1021/acs.est.5b02431

Hale, R. C., Seeley, M. E., La Guardia, M. J., Mai, L., and Zeng, E. Y. (2020). A global perspective on microplastics. J. Geophys. Res. 125:e2018jc014719. doi: 10.1029/2018jc014719

Hayes, K. A. (2003). Phylogeography and Evolution of the Florida Crown Conch (Melongena Corona). Tampa, FL: Scholar Commons.

Hendrickson, E., Minor, E. C., and Schreiner, K. (2018). Microplastic abundance and composition in Western lake superior as determined via microscopy, PyrGC/MS, and FTIR. Environ. Sci. Technol. 52, 1787-1796. doi: 10.1021/acs.est. $7 \mathrm{~b} 05829$

Hidalgo-Ruz, V., Gutow, L., Thompson, R. C., and Thiel, M. (2012). Microplastics in the marine environment: a review of the methods used for identification and quantification. Environ. Sci. Technol. 46, 3060-3075. doi: 10.1021/es2031505

Iliff, S. M., Wilczek, E. R., Harris, R. J., Bouldin, R., and Stoner, E. W. (2020). Evidence of microplastics from benthic jellyfish (Cassiopea xamachana) in Florida estuaries. Mar. Pollut. Bull. 159:111521. doi: 10.1016/j.marpolbul.2020. 111521

Ivar do Sul, J. A., Costa, M. F., Barletta, M., and Cysneiros, F. J. A. (2013). Pelagic microplastics around an archipelago of the Equatorial Atlantic. Mar. Pollut. Bull. 75, 305-309. doi: 10.1016/j.marpolbul.2013.07.040

Krueger, R. (2021). Five Facts: Limpkins in Florida. [online] Florida Museum. Available online at: https://www.floridamuseum.ufl.edu/science/five-factslimpkins/ (accessed 9 June 2021)

Limaverde, A. M., de, L., Rebello Wagener, A., Fernandez, M. A., de, L., Scofield, A., et al. (2007). Stramonita haemastoma as a bioindicator for organotin contamination in coastal environments. Mar. Environ. Res. 64, 384-398. doi: 10.1016/j.marenvres.2007.03.001

Lindeque, P. K., Cole, M., Coppock, R. L., Lewis, C. N., Miller, R. Z., Watts, A. J. R., et al. (2020). Are we underestimating microplastic abundance in the marine environment? A comparison of microplastic capture with nets of different mesh-size. Environ. Pollut. 265:114721. doi: 10.1016/j.envpol.2020.11 4721

Lu, F., Langenbacher, A., and Chen, J.-N. (2016). Transcriptional regulation of heart development in zebrafish. J. Cardiovasc. Dev. Dis. 3:14. doi: 10.3390/ jcdd3020014

Malmstadt, J., Scheitlin, K., and Elsner, J. (2009). Florida hurricanes and damage costs. Southeast. Geogr. 49, 108-131.

Masterson, J. (2008). Smithsonian Marine Station at Fort Pierce. Available online at: https://naturalhistory2.si.edu/smsfp/irlspec/Melongena_corona.htm (accessed December 21, 2020).

McEachern, K., Alegria, H., Kalagher, A. L., Hansen, C., Morrison, S., and Hastings, D. (2019). Microplastics in Tampa Bay, Florida: abundance and variability in estuarine waters and sediments. Mar. Pollut. Bull. 148, 97-106. doi: 10.1016/j. marpolbul.2019.07.068
NOAA (2021). What Are Microplastics? Available online at: https://oceanservice noaa.gov/facts/microplastics.html\#: \{\}\}:text=Microplastics\%20are\%20small\% 20plastic\%20pieces, our\%20ocean\%20and\%20aquatic\%20life.\&text=Plastic\% 20is\%20the\%20most\%20prevalent, our\%20ocean\%20and\%20Great\%20Lakes (accessed December 22, 2020).

O'Connor, R. (2018). The Crown Conch - A Slow Predator of the Estuary. Panama, FL: Panhandle Outdoors.

Ogunola, O. S., Onada, O. A., and Falaye, A. E. (2018). Mitigation measures to avert the impacts of plastics and microplastics in the marine environment (a review). Environ. Sci. Pollut. Res. 25, 9293-9310. doi: 10.1007/s11356-018-1499-z

Peters, C. A., Thomas, P. A., Rieper, K. B., and Bratton, S. P. (2017). Foraging preferences influence microplastic ingestion by six marine fish species from the Texas Gulf Coast. Mar. Pollut. Bull. 124, 82-88. doi: 10.1016/j.marpolbul.2017. 06.080

Phillips, M. B., and Bonner, T. H. (2015). Occurrence and amount of microplastic ingested by fishes in watersheds of the Gulf of Mexico. Mar. Pollut. Bull. 100, 264-269. doi: 10.1016/j.marpolbul.2015.08.041

Plee, T. A., and Pomory, C. M. (2020). Microplastics in sandy environments in the Florida Keys and the panhandle of Florida, and the ingestion by sea cucumbers (Echinodermata: Holothuroidea) and sand dollars (Echinodermata: Echinoidea). Mar. Pollut. Bull. 158:111437. doi: 10.1016/j.marpolbul.2020. 111437

R Core Team (2014). R: A Language and Environment for Statistical Computing. Vienna: R Foundation for Statistical Computing.

Randall (2013). Crown Conchs- Friend or Foe? Tallahassee, FL: The WFSU Ecology Blog.

Rezania, S., Park, J., Md Din, M. F., Mat Taib, S., Talaiekhozani, A., Kumar Yadav, K., et al. (2018). Microplastics pollution in different aquatic environments and biota: a review of recent studies. Mar. Pollut. Bull. 133, 191-208. doi: 10.1016/j. marpolbul.2018.05.022

Richardson, T. D., and Brown, K. M. (1992). Predation risk and feeding in an intertidal predatory snail. J. Exp. Mar. Biol. Ecol. 163, 169-182. doi: 10.1016/ 0022-0981(92)90047-e

Romeo, T., Pietro, B., Pedà, C., Consoli, P., Andaloro, F., and Fossi, M. C. (2015). First evidence of presence of plastic debris in stomach of large pelagic fish in the Mediterranean Sea. Mar. Pollut. Bull. 95, 358-361. doi: 10.1016/j.marpolbul. 2015.04.048

Setälä, O., Norkko, J., and Lehtiniemi, M. (2016). Feeding type affects microplastic ingestion in a coastal invertebrate community. Mar. Pollut. Bull. 102, 95-101.

Seuront, L. (2018). Microplastic leachates impair behavioural vigilance and predator avoidance in a temperate intertidal gastropod. Biol. Lett. 14:20180453. doi: 10.1098/rsbl.2018.0453

Shim, W. J., and Thomposon, R. C. (2015). Microplastics in the Ocean. Arch. Environ. Contam. Toxicol. 69, 265-268. doi: 10.1007/s00244-015-0216-x

Shoreline Park South (2020). City of Gulf Breeze. Available online at: https://cityofgulfbreeze.us/parks-and-recreation-department/shoreline-south/ (accessed December 22, 2020).

Sussarellu, R., Suquet, M., Thomas, Y., Lambert, C., Fabioux, C., Pernet, M. E. J., et al. (2016). Oyster reproduction is affected by exposure to polystyrene microplastics. Proc. Natl. Acad. Sci. U.S.A. 113, 2430-2435. doi: 10.1073/pnas. 1519019113

Tunnell, J. W., Dunning, K. H., Scheef, L. P., and Swanson, K. M. (2020). Measuring plastic pellet (nurdle) abundance on shorelines throughout the Gulf of Mexico using citizen scientists: establishing a platform for policy-relevant research. Mar. Pollut. Bull. 151:110794. doi: 10.1016/j.marpolbul.2019.110794

Van Cauwenberghe, L., and Janssen, C. R. (2014). Microplastics in bivalves cultured for human consumption. Environ. Pollut. 193, 65-70. doi: 10.1016/j.envpol. 2014.06.010

Von Moos, N., Burkhardt-Holm, P., and Köhler, A. (2012). Uptake and effects of microplastics on cells and tissue of the blue mussel Mytilus edulis L. after an experimental exposure. Environ. Sci. Technol. 46, 11327-11335. doi: 10.1021/ es302332w

Waite, H. R., Donnelly, M. J., and Walters, L. J. (2018). Quantity and types of microplastics in the organic tissues of the eastern oyster Crassostrea virginica and Atlantic mud crab Panopeus herbstii from a Florida estuary. Mar. Pollut. Bull. 129, 179-185. doi: 10.1016/j.marpolbul.2018.02.026

Walkinshaw, C., Lindeque, P. K., Thompson, R., Tolhurst, T., and Cole, M. (2020). Microplastics and seafood: lower trophic organisms at highest risk 
of contamination. Ecotoxicol. Environ. Saf. 190:110066. doi: 10.1016/j.ecoenv. 2019.110066

Waller, C. L., Griffiths, H. J., Waluda, C. M., Thorpe, S. E., Loaiza, I., Moreno, B., et al. (2017). Microplastics in the Antarctic marine system: an emerging area of research. Sci. Total Environ. 598, 220-227. doi: 10.1016/j.scitotenv.2017.0 3.283

Wang, W., Yuan, W., Chen, Y., and Wang, J. (2018). Microplastics in surface waters of Dongting Lake and Hong Lake, China. Sci. Total Environ. 633, 539-545. doi: 10.1016/j.scitotenv.2018.03.211

Ward, J. E., Zhao, S., Holohan, B. A., Mladinich, K. M., Griffin, T. W., Wozniak, J., et al. (2019). Selective ingestion and egestion of plastic particles by the blue mussel (Mytilus edulis) and Eastern oyster (Crassostrea virginica): implications for using bivalves as bioindicators of microplastic pollution. Environ. Sci. Technol. 53, 8776-8784. doi: 10.1021/acs.est.9b02 073

Watanabe, J. T., and Young, C. M. (2005). Feeding habits and phenotypic changes in proboscis length in the southern oyster drill, Stramonita haemastoma (Gastropoda: Muricidae), on Florida sabellariid worm reefs. Mar. Biol. 148, 1021-1029. doi: 10.1007/s00227-005-0152-9

Watts, A. J. R., Lewis, C., Goodhead, R. M., Beckett, S. J., Moger, J., Tyler, C. R., et al. (2014). Uptake and retention of microplastics by the shore crab Carcinus maenas. Environ. Sci. Technol. 48, 8823-8830. doi: 10.1021/es501 090e

Wessel, C. C., Lockridge, G. R., Battiste, D., and Cebrian, J. (2016). Abundance and characteristics of microplastics in beach sediments: insights into microplastic accumulation in northern Gulf of Mexico estuaries. Mar. Pollut. Bull. 109, 178-183. doi: 10.1016/j.marpolbul.2016.06. 002

Whitaker, J. M., Garza, T. N., and Janosik, A. M. (2019). Sampling with Niskin bottles and microfiltration reveals a high prevalence of microfibers. Limnologica 78:125711. doi: 10.1016/j.limno.2019.125711

Whitenack, L. B., and Herbert, G. S. (2015). Did shell-crushing crabs trigger an escalatory arms race in the aftermath of a Late Neogene regional mass extinction event? An experimental test. Palaeogeogr. Palaeoclimatol. Palaeoecol. 417, 57-65. doi: 10.1016/j.palaeo.2014.09. 026

Wickham, H. (2009). ggplot2: Elegant Graphics for Data Analysis. New York: Springer.
Wightman, E. (2020). The Microscopic Threat with a Macroscopic Impact: Microplastics Along the Southeast Florida Reef Tract. Master's thesis. Fort Lauderdale, FL: Nova Southeastern University.

Wilcoxon, F. (1945). Individual comparisons by ranking methods. Biom. Bull. 1, 80-83.

Wright, S. L., Thompson, R. C., and Galloway, T. S. (2013). The physical impacts of microplastics on marine organisms: a review. Environ. Pollut. 178, 483-492. doi: 10.1016/j.envpol.2013.02.031

Yu, S.-P., and Chan, B. K. K. (2020). Effects of polystyrene microplastics on larval development, settlement, and metamorphosis of the intertidal barnacle Amphibalanus amphitrite. Ecotox. Environ. Saf. 194:110362.

Yu, S.-P., Cole, M., and Chan, B. K. K. (2020). Effects of microplastic on zooplankton survival and sublethal responses. Oceanogr. Mar. Biol. Oceanogr. Mar. Biol. 58, 351-394.

Yu, X., Ladewig, S., Bao, S., Toline, C. A., Whitmire, S., and Chow, A. T. (2018). Occurrence and distribution of microplastics at selected coastal sites along the southeastern United States. Sci. Total Environ. 613-614, 298-305. doi: 10.1016/ j.scitotenv.2017.09.100

Zhu, C., Li, D., Sun, Y., Zheng, X., Peng, X., Zheng, K., et al. (2019). Plastic debris in marine birds from an island located in the South China Sea. Mar. Pollut. Bull. 149:110566. doi: 10.1016/j.marpolbul.2019.110566

Conflict of Interest: The authors declare that the research was conducted in the absence of any commercial or financial relationships that could be construed as a potential conflict of interest.

Publisher's Note: All claims expressed in this article are solely those of the authors and do not necessarily represent those of their affiliated organizations, or those of the publisher, the editors and the reviewers. Any product that may be evaluated in this article, or claim that may be made by its manufacturer, is not guaranteed or endorsed by the publisher.

Copyright (c) 2021 Kleinschmidt and Janosik. This is an open-access article distributed under the terms of the Creative Commons Attribution License (CC BY). The use, distribution or reproduction in other forums is permitted, provided the original author(s) and the copyright owner(s) are credited and that the original publication in this journal is cited, in accordance with accepted academic practice. No use, distribution or reproduction is permitted which does not comply with these terms. 